TARNOWSKIE STUDIA TEOLOGICZNE 35 (2016) NR 2, S. 175-178

http://dx.doi.org/10.15633/tst.2114

dk. Adam Cieśla

UNIWERSYTET PAPIESKI JANA PAWŁA II W KRAKOWIE

\title{
Rzecz o drogocennej słomie. Sprawozdanie z wręczenia księgi jubileuszowej ks. prof. dr. hab. Antoniemu Paciorkowi \\ (Tarnów, 7 marca 2016 roku)
}

Według przekazów hagiograficznych święty Tomasz, doznawszy pod koniec życia szczególnego wglądu w wielkość Bożej chwały, określił całość swych intelektualnych poszukiwań mianem słomy - na pierwszy rzut oka tytułem mało chwalebnym. Wyraził w ten sposób nikłość ludzkich możliwości poznawczych w zderzeniu z transcendencją Boga. Wyraził również kruchość ludzkich słów, które ciągle nie mogą dorosnąć do wielkości opisywanej tajemnicy. Niemniej sam Bóg ową kruchość ludzkich słów przyjął i pobłogosławił, czego wyrazem jest Pismo Święte, które łączy ludzką mowę z Bożą prawdą. Tradycja Kościoła również ukazuje ludzką myśl, sięgającą Bożych skarbów. Najwyższy wyraz prawdy o tym, że nędza moralna i słabość poznawcza nie rysują w sposób absolutny oblicza człowieczeństwa, stanowi tajemnica wcielenia, w której Boże Słowo przyjęło kruche ludzkie ciało.

Kruchość słów ludzkich jednak ukazuje Boga. Z tej też racji rzeczą świętego Tomasza jest wyznanie pokory, a rzeczą synów Kościoła jest uznanie drogocenności jego nauk, wspaniałości słomy. Owo uznanie ma wielorakie przejawy. Przejawia się ono również w Wyższym Seminarium Duchownym w Tarnowie, szczególnie w corocznym celebrowaniu 7 marca uroczystego wspomnienia ku czci patrona wspólnoty - Doktora Anielskiego.

Szczytem, a zarazem właściwym początkiem obchodów odpustowych, było sprawowanie Najświętszej Ofiary, której przewodniczył ks. bp Leszek Leszkiewicz, jeszcze nie tak dawno prefekt w tarnowskim seminarium. Celebrans zaznaczył, że geniusz świętego Tomasza polegał przede wszystkim na zjednoczeniu z Bogiem. Wezwał do porzucania mądrości ziemskiej na rzecz mądrości krzyża, która jest niemożliwa bez stanu łaski uświęcającej. 
Następnie, o godz. 10.30, w auli im. św. Jana Pawła II rozpoczęła się akademia odpustowa. Po śpiewie $O$ Thoma laus wykonanym przez chór seminaryjny, rektor ks. dr hab. Andrzej Michalik przywitał przybyłych gości, na czele z ks. bp. Andrzejem Jeżem, biskupami pomocniczymi oraz profesorami, a wśród nich ks. prof. dr. hab. Antonim Paciorkiem przeżywającym siedemdziesiąte urodziny. W krótkim wystąpieniu ksiądz rektor scharakteryzował świętego Tomasza jako mistrza sztuki myślenia, dla którego fundament poszukiwań intelektualnych stanowiła Biblia.

Refleksji wprowadzającej dokonał ks. dr. hab. Janusz Królikowski, prof. UPJPII i dziekan Wydziału Teologicznego, zarysowując treść wykładu inauguracyjnego świętego Tomasza na paryskim uniwersytecie. W owym wykładzie Doktor Anielski, odwołując się do Psalmu 103, przyrównał nauczycieli i świętych doktorów do gór, które jako pierwsze są oświecane promieniami słońca, stanowią naturalną obronę terytorium przed wrogami i łączą ziemię z niebem. Liryzm tego porównania pozwala wielorako uchwycić istotne obowiązki świętych doktorów, którzy badają sfery natury i łaski, szybko rozpoznają światła Objawienia i obroty myśli oraz dzielnie bronią prawdy i demaskują fałsz. Szerokość zadań nauczycielskich domaga się Boga jako przekaziciela Mądrości propria virtute. Nauczyciel czerpie zatem z wiecznotrwałych świętych źródeł, których sercem jest słowo Boże.

Ta ogólna refleksja swą konkretyzację znalazła w całożyciowej postawie ks. prof. dr. hab. Antoniego Paciorka, co wyraził dziekan ks. Janusz Królikowski, jak i ks. prof. dr hab. Tadeusz Brzegowy, któremu przypadło w udziale wygłoszenie pochwały dostojnego Jubilata. Nakreślił w niej drogę życia ks. Antoniego Paciorka, podkreślając jego zasługi na polu biblijnym i translatorskim. Dostojny Jubilat tłumaczył Arystotelesa, jak i czytania brewiarzowe. Podjął również wielkie dzieło wydawania serii Nowych Komentarzy Biblijnych. Inną zasługą Księdza Profesora jest zapoczątkowanie serii Scipturae Lumen. Ksiądz Brzegowy wskazał także na znaczenie książek ks. Paciorka, bowiem przybliżają one polskiemu czytelnikowi nowe osiągnięcia egzegezy. Zwieńczeniem laudacji, łączącej wyrazistość pochwał i ich odpowiedniość z zasługami, było wręczenie księgi pamiątkowej przez ks. bp. Andrzeja Jeża.

Następnie głos zabrał sam Jubilat. Wpierw wyraził wdzięczność za wieloraką życzliwość, której materialny znak stanowi wręczona księga pamiątkowa. Następnie przeszedł do wykładu o tytule: Słowo Boże w życiu Kościoła. Stwierdził, że uczynienie zadość tematowi przedłożenia domaga się wpierw uwag w kwestii roli słowa Bożego w życiu Jezusa. Zauważył, że Chrystusowe 
głoszenie, dokonujące się w czasie i przestrzeni, jest objawieniem tajemnicy Jego osoby; tego, co było przedtem - wcielenia, jak i tego, co było potem, a więc męki i zmartwychwstania.

Ksiądz Antoni Paciorek podkreślił, że przyjście Jezusa jest pełnią w stosunku do wielokrotnie i na różne sposoby kierowanych słów przez proroków $($ Hbr 1, 1). Jezus głosił w Judei i Galilei nadejście królestwa Bożego i wezwanie do nawrócenia. Owo głoszenie ma swoją kontynuację; istnieje również głoszenie secundum spiritum; Jezus przemawia nadal, choć w inny sposób. Głoszenie secundum spiritum znajdujemy już w Apokalipsie w listach do siedmiu Kościołów: „To mówi Syn Boży” (Ap 2, 18), „To mówi Amen”(Ap 3, 14). Ksiądz Profesor przywołał fragment konstytucji Dei Verbum: „Bóg, który niegdyś przemówił, rozmawia bez przerwy z Oblubienicą swego Syna ukochanego, a Duch Święty, przez którego żywy głos Ewangelii rozbrzmiewa w Kościele, a przez Kościół w świecie, wprowadza wiernych we wszelką prawdę oraz sprawia, że słowo Chrystusowe obficie w nich mieszka (DV 8)".

Rozważając głoszenie secundum spiritum, Ksiądz Profesor uwypuklił liturgię jako główne miejsce przepowiadania. Płaszczyzna liturgii posłużyła do zestawienia eucharystycznej tajemnicy ze znaczeniem słowa Bożego. $\mathrm{Z}$ tego zestawienia Ksiądz Profesor wyprowadził znaczące teologicznie konsekwencje. Eucharystia w Starym Testamencie funkcjonowała jako zapowiedź, pod osłoną figur. W świetle Nowego Testamentu ujmujemy ją jako wydarzenie ofiary - jednorazowej śmierci Chrystusa na krzyżu. Ofiara krzyżowa jest uobecniana w liturgii. Można zatem dostrzec trzy punkty eucharystycznej tajemnicy: starotestamentalną zapowiedź, historyczne wydarzenie śmierci na krzyżu i ciągłe, liturgiczne uobecnianie.

Analogicznie, na trzech poziomach, można ujmować słowo Boże. Wpierw mamy słowa proroków, które są figurami i zapowiedziami. Aż do Jana Chrzciciela natchnienie prorockie określała formuła: stało się słowo Boże. Trwa ona aż do historycznego objawienia się Jezusa, a więc Słowa, które stało się Ciałem. W Chrystusie Pisma znajdują wypełnienie. Na trzecim poziomie słowo jest uobecniane w liturgii, albowiem Duch Święty niejako je w wierzących nieustannie aktywuje. W tym uobecnianiu kryje się podobieństwo do sakramentu.

Uprawnione jest zatem mówienie o sakramentalności słowa Bożego. Sakrament najprościej definiuje się jako znak widzialny łaski niewidzialnej. Eucharystia jest $\mathrm{w}$ najwyższej mierze sacramentum visibile. Słowo Boże natomiast można określić jako sacramentum audibile. Sakramenty wychodzą 
naprzeciw cielesnej, zmysłowej naturze człowieka, a słowa Pisma odnoszą się konkretnie do słuchu. Interwencja Ducha Świętego czyni z kontaktu z Pismem - spotkanie z Jezusem. Słowo Boże, podobnie jak sakrament, w zwyczajności znaku, czytanych wyrazów, przynosi niezwykły skutek o duchowej naturze. Stąd też w historii Kościoła, podczas zebrań chrześcijańskich, wcześnie połączono liturgię słowa z liturgią eucharystyczną, przeczuwając odpowiedniość między Eucharystią i sakramentalnością słowa Bożego.

W liturgii Kościoła Jezus przemawia według ducha - secundum spiritum. Prostota Boga przychodzącego pod osłoną liter i chleba budzi zdumienie, ale też oburzenie, które przypomina biblijne niezadowolenie Naamana gorszącego się tym, że ma być uzdrowiony w banalny sposób, w małej rzece, jaką jest Jordan.

W liturgii Pismo Święte otrzymuje nowe znaczenie, które nie zamyka się w poznaniu treści ksiąg, lecz podprowadza ku Temu, którego przyjmie się za chwilę pod postacią chleba. Typ tego procesu stanowi Emaus, w którym uczniowie poznali Pana przy łamaniu chleba, a wcześniej jeszcze byli syceni wypowiadanymi przez Niego słowami. W liturgii słowa Jezus daje poznać cząstkę siebie, a potem w Ciele daje siebie cały. Słowa Pisma tworzą dialog człowieka z Bogiem, którego kulminację stanowi konsekracja.

W swym przedłożeniu Ksiądz Profesor ukazał słowo Boże w jego łączności z eucharystyczną tajemnicą. Nakreślił piękno idei sakramentalności, w ramach której Bóg przychodzi do człowieka w sposób pokorny, związany z ludzką naturą.

Po okolicznościowym wykładzie Księdza Profesora, łączącym jasność wywodu z głębią myśli, nastąpiła prezentacja obrazka scenicznego pt. Vita Thomae. Przedstawienie zostało przygotowane przez alumnów II roku i stanowiło próbę syntetycznego ujęcia życia świętego Tomasza oraz nowości jego filozoficznych poszukiwań. Akademię zwieńczyły słowa ks. bp. Andrzeja Jeża, w których jeszcze raz zaznaczył cenność naukowych badań, jak i duszpasterskich działań podejmowanych przez ks. Antoniego Paciorka.

Najwyższy przyjmuje niskość ludzkich liter oraz nikłe postaci chleba i wina, co objawia żarliwość Jego miłości. Pokora słów wznieca łaskę. W imię tej samej Bożej pokory katolicy z uważnością przyjmują Tradycję, w ramach której słowa o Bogu kreślą ludzie pełni Bożego natchnienia. Rzeki myśli świętych doktorów spotykają się u źródła, jakim jest właśnie słowo Boże. Jedną z rzek, szczególną i potężną, stanowi myśl świętego Tomasza. Swą chwalebną cząstkę w tychże rzekach Bożej prawdy ma również ks. Antoni Paciorek, rzetelny i wierny badacz słów Mądrości. 